\title{
Penentuan Kadar Protein Pada Ampas Bir Limbah Industri Pabrik Bir
}

\author{
Determination of Protein Levels On Dregs of Beer Result of Industrial Waste on Beer Factory)
}

\author{
Reni Feginanda ${ }^{1}$, Soebiyanto ${ }^{1 *}$, dan Petrus Darmawan ${ }^{2}$ \\ ${ }^{1}$ Program Studi D-III Analis Kesehatan Fakultas Ilmu Kesehatan, Universitas Setia Budi Surakarta \\ ${ }^{2}$ Program studi S1-Teknik Kimia Fakultas Tehnik, Universitas Setia Budi Surakarta \\ *Corresponding author: soebixto@gmail.com
}

\section{ABSTRAK}

Ampas bir merupakan residu dari limbah industri yang telah diambil sarinya melalui proses pengolahan dengan bahan baku malt yang berasal dari biji barley. Ampas bir oleh masyarakat dimanfaatkan sebagai susbtitusi pakan untuk ternak. Apabila diperhatikan ampas bir dalam ketersediaan dan kontinuitas pengadaannya sudah mencukupi, sehingga masyarakat bisa lebih mudah dalam mendapatkannya. Penelitian ini bertujuan untuk menentukan kadar protein pada ampas bir.

Sampel dalam penelitian ini berupa ampas bir yang diperoleh dari distributor ampas bir di Kota Wonogiri. Penentuan kadar protein pada ampas bir yaitu menggunakan metode Gunning. Penentuan kadar protein ini melalui tiga tahap yaitu tahap dekstruksi, tahap destilasi, dan tahap titrasi. Kadar protein pada sampel ampas bir dihitung berdasarkanjumlah Nitrogen dikalikan dengan faktor konversi dari ampas bir yaitu Malt.

Hasil penelitian menunjukkan bahwa kadar protein pada ampas bir adalah 9,45\%

Kata kunci: ampas bir, protein

\section{ABSTRACT}

Dregs ofbeer is from the residue of industrial waste has been taken filtrat through processing with malt raw material that comes from the seeds for barley. Dregs of beer by the community used as livestock feed ingredients for replacement cattle. When the attention dregs of beer in the availability and continuity of method of procurement is sufficient so that the community can be more easily to get it. This research aims to determine the level of protein in the dregs of beer.

Samples in this research form dregs of beer obtained from the dregs of beer suppliersin city of Wonogiri. Determination of protein levels on dregs of beer using Gunning method. Determination of protein levels through three stages namely dekstruksi stage, destilasi stage, and titration stage. The level of protein on dregs of beer samples is calculated based on the amount of Nitrogen beer multiplied by the conversion factor from the dregs of beer is Malt.

The results of the study showed that the protein levels on the dregs of beeris $9,45 \%$

Keywords: dregs of beer, protein

\section{PENDAHULUAN}

Bir adalah minuman ringan beralkohol dengan kadar 3\%-6\% yang dibuat dengan memfermentasikan bahan-bahan seperti malt yang berasal dari biji barley dan hop serta bahan lainnya menggunakan ragi. Kebanyakan bir biasanya diberi perasa yang berasal dari bunga hop (pemberi rasa pahit dan aroma bir) juga sebagai pengawet, walaupun sering juga di beri perasa yang berasal dari tumbuhan atau buahbuahan lain (Arlene, 2011). Di dalam industri pembuatan bir menghasilkan limbah cair dan limbah padat. Limbah padat dari proses pembuatan bir disebut sebagai ampas bir.
Ampas bir merupakan limbah industri dari pembuatan bir yang menggunakan bahan biji barleydan bahan lain berkadar maltosa tinggi sebagai bahan utama. Ampas bir yang disimpan dalam wadah tertutup, akan mengalami proses fermentasi secara alami, karena mengandung bakteri pembentuk asam laktat. Adanya proses fermentasi dapat meningkatkan kandungan protein dan daya cerna (Hartini, 2008).Ampas bir dapat memberi arti ekonomis dengan dijadikan sebagai pakan ternak untuk penggemukan seperti ternak sapi. Menurut Surtleff dan Aoyagi (1979) dalam Tangkas (2012) melaporkan bahwa penggunaan ampas 
bir sangat baik digunakan sebagai ransum ternak sapi perah karena mengandung protein cukup tinggi.

Di kalangan masyarakat khususnya Jawa Tengah ampas bir dimanfaatkan sebagai pakan ternak. Masyarakat meyakini bahwa ampas bir dapat digunakan sebagai pakan pengganti untuk penggemukan hewan seperti sapi, domba, ayam, dan hewan ternak lainnya. Penggunaan ampas bir dirasa lebih murah dan mudah didapatkan, sehingga mempermudah bagi peternak untuk menggunakannya. Tujuan dari penelitian ini adalah untuk mengetahui kadar protein yang terkandung dalam ampas bir hasil limbah industri pabrik bir.

\section{METODE PENELITIAN}

Penelitian ini dilakukan di Laboratorium Analisa Makanan dan Minuman Universitas Setia Budi Surakarta. Waktu penelitian dilaksanakan pada bulan Januari 2017. Sampel pada penelitian ini digunakan ampas bir yang dibeli dari distributor yang ada di kota Wonogiri.

\section{Prosedur Penetapan Kadar Protein}

\section{a. Tahap Dekstruksi}

Ditimbang sampel sebanyak 0,7-3 gram, dimasukkan dalam labu Kjeldahl. Ditambah 10 gram Natrium Sulfat Anhydrat dan 0,5 gram $\mathrm{CuSO}_{4} .5 \mathrm{H}_{2} \mathrm{O}$ serta $25 \mathrm{ml}$ Asam Sulfat Pekat p.a dan beberapa batu didih digojok hingga rata kemudian dipanaskan dengan api bunsen dalam lemari asam, dengan mulut labu Kjeldahl ditutup dengan corong dipanaskan dengan api kecil, setelah asap hilang api dibesarkan. Pema- nasan diakhiri setelah diperoleh cairan jernih (hijau terang) dalam labu Kjeldahl

\section{b. Tahap Destilasi}

Sampel didinginkan, kemudian ditambah 20-50 ml aquadest dan 1 gram serbuk $\mathrm{Zn}$. Larutan dibuat alkali dengan ditambahkan larutan $\mathrm{NaOH} 45 \%$ sebanyak 75-100 ml dan beberapa tetes indikator PP 1\%. Labu Kjeldahl dipasang pada alat destilat, kemudian diberi lapisan gips pada alat pipa U. Hasil destilasi ditampung dalam erlenmeyer yang berisi $25-50$ $\mathrm{ml}$ larutan $\mathrm{HCl} \pm 0,1 \mathrm{~N}$ yang ditambah dengan indikator PP $1 \%$. Destilasi diakhiri setelah tetesan dari destilat tidak berwarna merah lagi (larutan tidak bersifat basis)

\section{c. Tahap Titrasi}

Kelebihan $\mathrm{HCl}$ dititrasi dengan larutan $\mathrm{NaOH} \pm 0,1 \mathrm{~N}$ sampai berwarna merah muda yang konstan. Dilakukan titrasi blanko, yaitu 25 $\mathrm{ml} \mathrm{HCl} \pm 0,1 \mathrm{~N}$ ditambah indikator PP $1 \%$ kemudian dititrasi dengan larutan $\mathrm{NaOH} \pm 0,1 \mathrm{~N}$ (Sudarmadji et al., 1997)

Setelah data percobaan diperoleh, kemudian dilakukan perhitungan kadar protein sebagai berikut :

$\% \mathrm{~N}=\frac{(\mathrm{ml} \mathrm{NaOH} \text { Blanko }-\mathrm{ml} \mathrm{NaOH} \text { Sample })}{\mathrm{g} \text { Bahan } \mathrm{x} 1000} \times \mathrm{N} \mathrm{NaOH} \times 14,008 \times 100 \%$

Perhitungan kadar protein selanjutnya dikalikan dengan faktor konversi (Tabel 1), dengan rumus :

Kadar Protein $(\%)=\%$ N x F (faktor konversi)

Keterangan :

$\% \mathrm{~N}=$ Kadar unsur nitrogen

$\mathrm{F}=$ Faktor konversi untuk ampas bir adalah 6,25

Tabel 1. Faktor konversi kadar protein

\begin{tabular}{|c|l|c|}
\hline NO & \multicolumn{1}{|c|}{ JENIS } & FAKTOR \\
\hline 1. & $\begin{array}{l}\text { Bir, Siru, Biji-Bijian, Ragi, Makanan Ternak, Buah } \\
\text { Buahan, Teh, Malt, Anggur }\end{array}$ & 6,25 \\
\hline 2. & Beras & 5,95 \\
\hline 3. & Roti, Gandum, Makaroni, Bakmi & 5,70 \\
\hline 4. & Kacang Tanah & 5,46 \\
\hline 5. & Kedelai & 5,75 \\
\hline 6. & Kenari & 5,18 \\
\hline 7. & Susu Kental Manis & 6,38 \\
\hline
\end{tabular}




\section{HASIL DAN PEMBAHASAN}

Berdasarkan hasil percobaan, kadar protein ampas bir diperoleh hasil di Tabel 2 .

Setelah dilakukan perhitungan didapatkan rata-rata kadar protein pada ampas bir hasil limbah industri pabrik bir adalah 9,45\%.

Metode Gunning merupakan salah satu metode penentuan protein secara kuantitatif. Kelebihan dari metode Gunning adalah masih digunakan secara luas dan merupakan metode standar dibandingkan dengan metode lain, karena dapat diaplikasikan pada semua jenis bahan makanan. Metode ini tidak memerlukan biaya yang mahal dan juga akurat untuk penentuan protein kasar. Disamping mempunyai kelebihan, metode Gunning juga mempunyai kelemahan diantaranya yaitu tidak semua jenis protein mengandung jumlah $\mathrm{N}$ yang sama, kelemahan lainnya adalah didalam bahan terdapat senyawa lain bukan protein yang mengandung unsur $\mathrm{N}$, meskipun jumlahnya lebih sedikit dari protein. Senyawa-senyawa bukan protein yang mengandung $\mathrm{N}$ misalnya seperti amonia, asam amino bebas dan asam nukleat.

Karakteristik umum beberapa jenis pakan asal limbah seperti ampas bir ditandai dengan kandungan protein yang rendah dan fraksi serat yang tinggi. Limbah dengan karakteristik demikian sesuai jika digunakan sebagai bahan pakan ternak ruminansia. Nilai manfaat dari limbah akan meningkat dengan adanya suplementasi dan pemanfaatan probiotik. Contoh suplementasi pada pakan ternak yang sering dilakukan adalah suple-mentasi nitrogen non protein seperti urea yang diperkaya dengan mineral lain. Probiotik merupakan suatu bahan pakan suplemen berupa jasad hidup mikrobial yang mempunyai pengaruh menguntungkan bagi induk semang-nya dengan meningkatkan keseimbangan mikroba usus halus. Probiotik yang diberikan sebagai suplemen mempunyai dampak yang menguntungkan seperti perbaikan performan, produksi dan kesehatan ternak (Murni et al., 2008)

Minat masyarakat untuk menggunakan ampas bir sebagai substitusi pakan ternak sangat tinggi. Seperti contoh di luar negeri, menurut Heng-Chu, 2004 di Taiwan penggunaan ampas bir sebagai pakan sapi perah mencapai $5-10 \mathrm{~kg}$ per ekor per hari, sedangkan di Indonesia produksi ampas bir pada tahun 1983 mencapai 6.984 ton dengan penyebaran pemasaran ke Jawa Barat dan DKI Jakarta (Parwanto, 2007). Produksi ampas bir sebagai substitusi pakan ternak akan diikuti oleh kota-kota lain apabila dikota tersebut terdapat pabrik bir. Namun perlu diingat "batasan" tentang konsumsi bir di Indonesia yang juga akan mempengaruhi produksi ampas bir.

Menurut SNI 3148.2:2009 tentang sapi potong kadar protein minimal untuk penggemukan adalah $13 \%$. Parameter dalam penentuan kualitas suatu pakan tidak hanya melihat dari kandungan proteinnya, akan tetapi perlu dilakukan pemeriksaan komponen kimia lainnya seperti kandungan air, abu, lemak kasar, serat kasar, Ca, P, NDF, UDP, aflatoksin, dan TDN.

Masyarakat mengharapkan dalam penggunaan ampas bir sebagai substitusi pakan untuk ternak dapat memberikan dampak yang positif untuk meningkatkan produksi dan produktivitas ternak. Adanya substitusi pakan ini, akan membuat masyarakat tidak kesulitan dalam memperoleh pakan ternak mengingat

Tabel 2. Kadar Protein Ampas Bir

\begin{tabular}{|c|c|c|c|c|}
\hline NO & $\begin{array}{c}\text { Berat Bahan } \\
(\mathrm{g})\end{array}$ & $\begin{array}{c}\text { Titran NaOH } \\
\text { Blanko }(\mathrm{ml})\end{array}$ & $\begin{array}{c}\text { Titran NaOH } \\
\text { Sampel }(\mathrm{ml})\end{array}$ & Kadar Protein \% \\
\hline I. & 2,0024 & 32,50 & 10,60 & $9,45 \%$ \\
\hline II. & 2,0016 & 32,50 & 10,80 & $9,37 \%$ \\
\hline III. & 2,0031 & 32,50 & 10,40 & $9,53 \%$ \\
\hline
\end{tabular}


di musim tertentu misalnya musim kemarau pakan ternak sulit untuk didapatkan terutama pakan hijauan. Permasalahan seperti ketersediaan pakan hijau di musim kemarau yang sulit diperoleh dapat diatasi dengan adanya sustitusi ampas bir.

\section{KESIMPULAN DAN SARAN \\ Kesimpulan}

Berdasarkan hasil penelitian didapatkan kadar protein pada ampas bir hasil limbah industri pabrik bir sebesar 9,45\%.

\section{Saran}

Agar dapat dilakukan penetapan kandungan gizi selain protein dengan menggunakan sampel beberapa jenis ampas bir.

\section{DAFTAR PUSTAKA}

Anuragaja. 2012. Pengetahuan Bahan Makanan Ternak. (Online).
Arlene, A. dan A Prima Kristijarti. 2011. Laporan Penelitian Pembuatan Bir Jahe Emprit. Bandung: Fakultas Teknologi Industri, Universitas Katolik Parahyangan

Hartini, Sri. 2008. Pengaruh Penggunaan Ampas Bir Dalam Ransum Terhadap Kecernaan Bahan Kering Dan Bahan Organik Pada Domba Lokal Jantan. Skripsi. Surakarta: Fakultas Pertanian, Universitas Sebelas Maret

Juwono. 2007. Pengaruh Penggunaan Ampas Bir Dalam Ransum Terhadap Kecernaan Bahan Kering Dan Bahan Organik Kelinci New Zealand White Jantan. Skripsi. Surakarta: Fakultas Pertanian, Universitas Sebelas Maret

Murni, R., Akmal, GL., dan Ginting. 2008. Buku Ajar Teknologi Pemanfaatan Limbah untuk Pakan. Laboratorium Makanan Ternak. Fakultas Peternakan: Universitas Jambi

Parwanto. A. E., 2007. Pengaruh Penggunaan Ampas Bir dalam Ransum Terhadap Performan SapiPeranakan Ongole Jantan. Skripsi. Surakarta: Fakultas Pertanian, Universitas Sebelas Maret

Rianto, Edy., Oktrin T. P., dan Retno, A. 2005. Retensi Protein Pada Sapi Peranakan Ongole Jantan yang Diberi Pakan Ampas Bir sebagai Pengganti Konsentrat. Semarang: Fakultas Peternakan, Universitas Diponegoro

Sudarmadji, S., Haryono, B., dan Suhadi. 2003. Analisa Bahan Makanan dan Pertanian. Yogyakarta: Liberty

Winarno FG. 2004 Kimia Pangan dan Gizi. Jakarta: Gramedia 